\title{
The Freedom Fight: A Novel of Resistance and Freedom. A Translation by Pamela J. Olubunmi Smith of Adébáyọ Fálétí's Ọmọ Olókùn Eșin
}

\author{
Michael Oladejo Afolayan \\ Lead Consultant \\ M \& P Educational Consulting International \\ mafolayan@yahoo.com
}

The story entailed in Omọ Olókùn Eșin (The Freedom Fight) is straightforward. Àjàyí, the titular hero, starts off with the direct first-person narrative. The story starts off straight from the horse's mouth, setting the stage for all other active agents to render their own sides of the events, to which everyone else is not privy. Here is the snippet of the novel directly from the author's blurb:

Àjàyí, son of Council Chief Olókùn Eșin of Àgùn, seeks independence on behalf of his Òkè Ògùn kinsmen, independence from the oppressive Òkò, one of the principal regions of Yorùbáland. To this end he and his many friends - among them Àyộwí from Igboho, and Ibiwumi, the Otu Baale's daughter - who help him narrate this story, suffered untold hardships. In the beginning, the very countrymen he sought to liberate were opposed to the talk of independence because no one could really grasp the idea. However, in the end, Àjàyí prevailed.

Where shall we begin this tale? Which among the story's many episodes should one emphasize - is it Kọlájọ’s demonic rampage, or Ibiwumi’s calculated risk, or Lagbogun's greed and flagrant abuse of power and privilege? Incidents abound - highlights herein include the riot in Baba-Ode Townships; the fight at Idi Araba; the bizarre encounter in the market 
center at Igboho; even the scuffle outside Baale of İgbẹtì's compound; and, of course, many more of Àjàyís numerous acts of valour and defiance.

No doubt, Omọ Olókùn Eșin is a celebration of heroism of a renaissance mind - the titular hero and protagonist, Àjàyí, Ọmọ Olókùn Eșin. It is a carnival of memories to the people of Òkè Ôgùn, often poorly translated and known also as "Oyọ North." Both in its original form and in its translated rendition, the book is divided into 30 chapters. It is complemented and complimented by the translator's "Reading Guide" that comprises of the true-life photograph of Adébáyọ Fálétí in his stately regalia and sporting the characteristic heroic hunter's cap, among other things. Indeed, by the end of the translation, the 164-page Yorùbá edition had ballooned into a swapping 253-page document without losing the thematic strength of the novel, nor compromising the intents of the original author.

The Freedom Fight, true to its sub-title, is "a novel of resistance and freedom." It is divided into three main parts. The first part is captioned, "My Story." This is purely the translator's wits as the author did not provide a sub-title to this particular segment. However, the sub-title sheds a critical light into the first thirteen chapters of the novel, and the reader is able to gain a deeper insight into the background of the novel, akin to providing a contextual framework for the understanding of the entire creative work. The second part is captioned "Ibiwumi's Story." The direct narrative technique is astonishing as it draws straight from the horse's mouth as Àjàyí, the agent provocateur of the whole scene, first and foremost takes us behind the veil of history to carry us along a revolution that would shake the conscienceless power of what seems like one of the darkest times in Yorùbá history.

The cliché will always be true that, "The sea is never without its water even before the downpour of the rain," as the Yorùbá often say. Omọ Olókùn Eșin will always stand on its own merit as a novel extraordinaire and the creative process of Fálétí would never be in doubt. However, just as noted in the translation of Ogún Omọdé, Akiwumi İṣọlá's memoir, Pamela Smith's translation, The Freedom Fighter, makes Adébáyọ Fálétí's genius even more apparent. The style of the original presentation of the story is never lost. The translation presents the novel so succinctly that a competent bilingual reader is almost subconsciously reading the English narrative as if reading the Yorùbá text. Conveniently set for three sections, the first part is a direct narration of events from the vantage point of the hero, Àjàyí.

The first chapter sets the stage for the narrative style, the movements of the various themes, and the direction of conclusion of the cumulative end of the entire story. Here, Àjàyí Ọmọ Olókùn Ẹșin, the main character, who is also 
the titular hero and protagonist, provides the genesis of the story to be told and the events to be unfolded. The reader is introduced to the super-imposed servitude on the people of Òkè Ògùn as the reader witnesses the people of Otu laboriously harvest the thatching grass that was going to be head-hauled from the town of Otu all the way to Òò, the seeming capital of the slave masters. These were intended for erecting thatched huts and feeding the horses of the monarch, the Olumoko of Òkò. The people of Òkò are here introduced to the reader as "those lazy, shiftless Òkò" people who considered themselves to be privileged citizens and claimed to overlord the people of Ọyọ North (Òkè Ogun), their subjects, by virtue of their own "natural" and historical rights. It is in this opening chapter that we witness the rebellious protagonist who led, or at least planted the seed of, an insurrection against the taskmasters that would culminate into a mass mobilization and movement of the people, and of course, an unquenchable coup d'état of historical magnitude. Àjàyí refused to take orders. He insisted on doing nothing to the chagrin of the taskmasters. This would become a journey of no return, although not without serious repercussions on the lead rebel himself, and as the narrator rightly put it laconically and prophetically: "It was simply a matter of time, and I knew it. Such liberties, I realized, could not possibly remain ignored for too long. Sooner or later a disgruntled laborer was bound to insist that the overseer not only subject my back to the lash, same as everyone else's, but that he also keep a watchful eye on me..."

And that, precisely, is what would happen as events unfold. Mayhem ensues and the uncouth elements who lurched at Omọ Olókùn Esșin were no match for this rebellious one-man army, the renegade "slave" who bruised even the leader of the bunch, calling his bluff in the open field, let alone all those bondsmen who joined in forced sympathy for Rótì, the disgraced taskmaster. As would be expected, the foolhardy Àjàyí has brought upon his brothers, threats, and imminent punishments. He has become the audacious younger brother to the proverbial Dada, known for his inability to fight. The tongue lashing and fist pummeling would not deter Àjàyí from announcing his doctrine to the people of Otu that sacrificing their personal living of servitude would give rise to a global existence fraught with freedom and unabated enfranchisement. It has become a journey of no return.

The next twelve chapters would narrate the heroic escapade of Àjàyí, starting from his unapologetic narration of justification for his act of rebellion, to his arrest; his encounter with Ibiwumi, the princess, a kindred rebel spirit with gusto, who would become the backbone of a successful cultural revolution; the arranged escape from incarceration, thanks to Ibiwumi's loyalty; the ignominious termination of the chieftaincy title of his father, the Olókùn Eșin of Otu whose title has conferred the princely rights on Àjàyí; 
the recruitments and dispersal of co-conspirators; the burning down of the straw bales intended for Òkò; the physical altercation with the search party; the arrest and re-incarcerations at various sites. The convergence of the rebels is now completed as the prison in Ile Olosi has now become the meeting point for the rebels - Àjàyí, Ibiwumi, and Àyọwí, whose mission was to recruit more rebels in İgbẹt tì through their mutual friend, Kọ́lájọ.

The five chapters that follow constitute the second section in which by ballot, the narrative now switches to Ibiwumi. And so, we have the authentic revelation of the events ensuing following the escape of Àjàyí from the jail in Otu. Here we hear of the visit of the envoys from the palace of the Olumokò of Òò; the interrogation, arrest and further interrogation of Ibiwumi; the voluntary absolving of self from royal privileges by Ibiwumi and the ensuing chains of slave emancipations triggered by her actions; the arrest of Olókùn Eșin, Àjàyí's father and his big brother, who in their attempt at rescuing Ibiwumi were themselves wrestled to submission and eventually captured into slavery; this final tale of woe of Ibiwumi, brought all of three of them to tears and terminated the second part of the story.

The third section is revealed in the words of Àyọwí who, on parting with Àjàyí in Igboho, headed for İgbẹtì, where he met Kọ́lájọ and tactically conferred with him on the matter at hand; their tour of the Baale's compound and the preparation to welcome the evil prince, Lagbookun, from Òkò; the attempt of the prince at seducing and stealing Arinládé, a bequeathed lady whose powerless fiancé was already preparing for their wedding; the ferocious lurching and violent reaction of Àyọwí and Kọ́lájọ at the disrespectful invaders, leading to the liberation of Arinládé, and the arrest of the two heroes, an event that ended the third section.

In the fourth and final part of the novel he narrate reverts to the direct narrative technique from the mouth of the protagonist, Àjàyí. Here, the reader is intimated with the events after Àyọwín's ordeal and Kọ́lájọ’s supernatural performance. From here, Àjàyí was about to start his indoctrination lecture series when the violent noises of a throng was heard from a distance. This was brought about by a massive conflagration that would soon consume much of the Òkò town, the palace and the prison. The heroic deed of Àjàyí did not absolve him and his co-conspirators of being set aside as "sacrificial lambs" to appease the gods. To add insult to his injury, Àjàyí has lost one of the greatest supporters and fiercest fighters of his movement, Kọ́lájọ, to the inferno fire that destroyed a whole civilization! With the conspiracy of the loyal guard, Akoda, Àjàyí took the risk of taking an AWOL exit for rescuing his father and others that were billed for execution in Osoogun. Returning to the Naari shrine after the heroic rescue came with its own drama, but eventually, the battle was fought and won and with the heroic struggle prompted by Àjàyí, 
the people of Òkè Ògùn were free from the yoke of bondage under the Òkò people. The resistance paid off, and freedom was bought with a price and certainly earned with blood. What a great story carved in a novel, and a great translation that would bring together two unrelated linguo-cultural media!

In the context of Yorùbá rhetorics, when the Master Carver (Gbẹnàgbẹnà) completes the work of art, the burden shifts to the critics (Gbẹnugbẹnu) to appreciate or depreciate the quality of the craft and the finesse of the craftmanship. Critics of noted repute have evaluated the work that Smith did in this piece. For example, Akintunde Akinyemi, Professor of Yorùbá and Chair of Department of Languages, Literatures, and Cultures at the University of Florida, Gainesville, speaks to the quality of the work when he notes, among other things, “...The translator, Pamela Olubunmi Smith, captures wildly the original author's intent, language use, descriptive mechanism, and narrative techniques, as she retells a fascinating Yorùbá freedom story in marvelous English ..." Adeleke Adeeko, Humanities Distinguished Professor at Oho State University, commends Smith "...for bringing to the English language audience this story of passion in the season of freedom, one in which Adébáyọ Fálétí reveals the common ties that bind libidinal yearning to the slave's rebellion and affirms that love cannot be free where liberty cannot roam." Imafedia Okhamefa, a Professor of Philosophy and Chair of the Goodrich Scholarship Program at the University of Nebraska at Omaha, writes: "Arguably, all languages drink from the same well, the human well ... Pamela Olubunmi Smith's English translation of this Yorùbá novel with three narrators and sometimes elusive of semi-tantalizing narrative transitions confirms that she drinks from the same Yorùbá-English well... Smith's translation enables us to feel and experience the nuanced dimensions of a $19^{\text {th }}$-century Yorùbá world."

The gift of packaging and re-gifting works of Yorùbá classics in a language that has no cultural bearing to the Yorùbá language and culture, that is, the English language, without any significant cultural, linguistic or thematic losses, sets Smith's works apart from many of her peers. Anyone familiar with her English translations of Akínwùmí İṣọlá's Efúnșetán Aníwúrà, Olú Omọ Tinúbú and Ogún Omọdé would agree that Smith's talent of bringing the Yorùbá language to the corridor of the English users with such seamless ease is a talent rarely seen elsewhere and before her. Today, both Akínwùmí İṣọlá and Adébáyọ Fálétí have joined the pantheon of Yorùbá ancestors but their benign and soothing voices would remain loud and clear, booming across the landscape of the Anglo world, where these authors of Yorùbá classics no longer tread. Thanks in no small part to the efforts of Pamela Olubunmi Smith.

There is a special excitement and satisfaction that the fluent and creative delivery of Smith's translation style brings to the eyes and mind (even the heart) of the competent bilingual readers of the text. The skillful improvisation of 
appropriate lexicon to fill in the vacuum of occasional contextual disconnect between the Yorùbá language and the English language brings color and lucidity to the translation. Take, for example, the opening paragraph of the novel, in which Fálétí wrote (in Yorùbá):

Òòùn mú háíhái. Gbogbo ènìyàn ń yán hò fún ò̀ngbẹ.

Bàtà ń gbóná mọni lẹsẹ. Dòjé pàápàa tí a fi ń pa koríko ń gbóná mọni lọwọ. Bẹẹ ni ẹrú Baálẹ tí ó dúró tì wá sì ń kígbe pé kí a máa pa koríko sí i. Láàrin pápà ni a wà, tí à ń pa koríko beẹre tí a ó rù lọ sí Òkò tí a ó lọ fi sin àsingbà.

Here is Smith's rendition of the same (in English):

The blazing sun was at the zenith; its noon-day heat brutal and unabating. The breezeless, sweltering afternoon unleashed its torrid, humid fury for a scorcher the likes of which we had never felt before. Parched mortals dragged about listlessly, sweltering, withered from thirst. Our makeshift footwear, obviously no march for this infernal torment, seared our sore, swollen feet. The scorching handle of our harvesting scythe, like hot embers, branded our already blistered palms. Ordinarily, it would be unnerving enough even under the circumstances of our servitude without such elemental conspiracy. My frayed nerves, at the breaking point, hardly needed provocation from the harsh grating voice of of Baálè's servant barking orders at us at every turn as he marched from one end of the field to the other. By now we were mid-field, harvesting the thatching grass slated for delivery to Òkò. That, indeed, was one among many of our bondsmen's annual obligations to those lazy, shiftless Òkò.

The above first paragraph of the novel is rendered in 71 words in its original form, Fálétís Omọ Olókùn Eșin. In Smith's translation of the same, we read 158 words, which is more than double in lexical volumes when juxtaposed with the original text. This underscores the burden of the translator who must be the jury and the judge in determining what to bring from the secondary language to march the primary one. It takes the marriage of competence and confidence in the use of both languages for a translator to fiddle with such ingenious improvisation and succeed at doing it. Unquestionably, Smith is a master translator who confidently treads verges of two linguistic grounds and birthed the best of both (Afolayan, 2017). It is one thing to succeed at translating a complicated and sophisticated historical text like Omo Olókùn Eșin, it is another thing to translate and interpret the renaissance mind that resides inside the literary icon and cultural mogul of the Fálétí 
caliber. This is a magical act reserved only for a special class of rare cultural and language geniuses, artists, and master craftsmen and women. The intellectual magic wand that Pamela J. Olubunmi Smith pulled in accomplishing the task of this translation positions her in that extraordinary class. In his foreword to the text, the late Akínwùmí İṣọlá, a literary and cultural giant in his own right, one of the few endowed with the gift of helping to bring the most sacred of the Yorùbá culture into the popular space, put it right in his soft and lofty voice, as he writes: "Olubunmi Smith's significant achievement is that she made the story travel through the strange, uncomfortable English language terrain to arrive "with its vital organs still intact."' What else is there to say about the quality of work that Pamela Smith did in this translation? Needless to say, then, The Freedom Fight is the nearest imaginable translation of Omọ Olókùn Eșin into the English language. It represents the contents and contexts of this serious historical novel of Fálétí and together with the original Yorùbá text, this rendition will compliment and sustain the classical status of the monumental work, passing the test of time unabated and unalloyed.

\section{References}

Afolayan, M. O. "Akínwùmí İșọlá. Treasury of Childhood Memories. Translated by Pamela J. Olubunmi Smith." Yorùbá Studies Review 1.2 (2017): 173-184.

Fálétí, Adébáyọ Ọmọ Olókùn Eșin. Ibadan: Heinemann Educational Books. 1993.

Smith, Pamela J. Olubunmi. The Freedom Fight: A Novel of Resistance and Freedom. Africa World Press. 2010. 


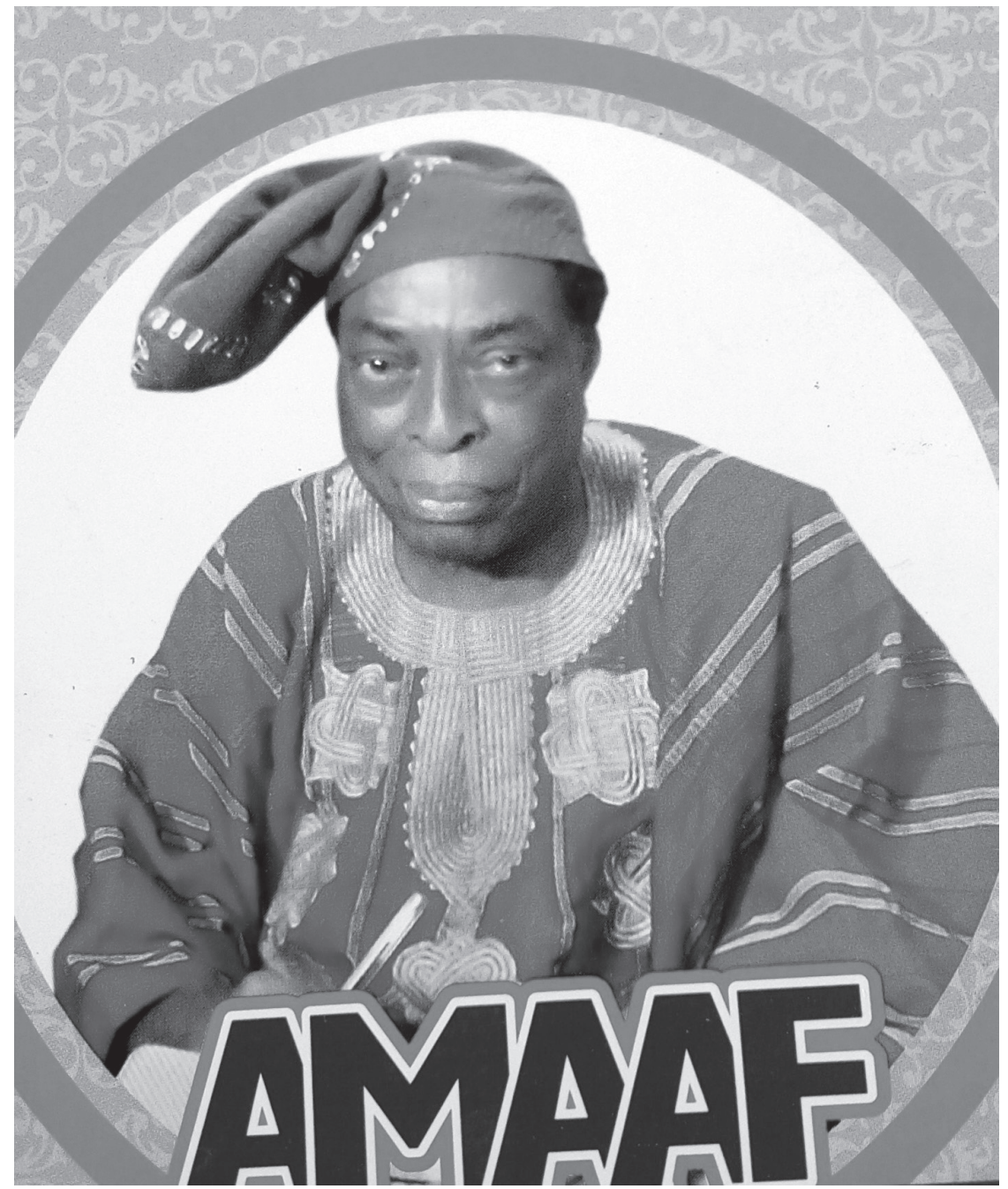

